granites from the Ketilidian mobile belt (early Proterozoic), South Greenland. (abstract). Annls Soc. géol. Belg. 94, 133 only.

Bridgwater, D. 1965: Isotopic age determinations from South Greenland and their geological setting. Bull. Gronlands geol. Unders. 53 (also Meddr Gronland 179, 4), 56 pp.

Dawes, P. R. 1968: Contrasted types of metamorphism of basic intrusions in the Precambrian basement of the Tasiussaq area, South Greenland. Bull. Gronlands geol. Unders. 71 (also Meddr Gronland 185, 4), 47 pp.

Ellitsgaard-Rasmussen, K. 1970: General review of the Survey's activities in 1969. Rapp. Grønlands geol. Unders. 28, 5-9.

McIntyre, G. A., Brooks, C., Compston, W. \& Turek, A. 1966: The statistical assessment of $\mathrm{Rb}-\mathrm{Sr}$ isochrons. J. geophys. Res. 71, 5459-5468.

\title{
U/Pb ZIRCON STUDIES ON THE AGE AND ORIGIN OF POST-TECTONIC INTRUSIONS FROM SOUTH GREENLAND
}

\author{
B. L. Gulson and T. E. Krogh \\ Geological interpretations in collaboration with D. Bridgwater
}

The samples used in the age dating programme reported on here were collected in the summer of 1970 as part of a regional mapping programme with J. R. Andrews, D. Bridgwater, B. L. Gulson and J. S. Watterson (see Andrews et al., 1971). Owing to the extensive weathering, samples were obtained by drilling and blasting. All except the most northern sample localities are indicated in fig. 6 .

\section{Aim of the investigation}

The main objects were to establish the precise time of emplacement of a major suite of post-tectonic intrusions which occur throughout South Greenland, and to date the main metamorphic events in the surrounding country rocks to test whether these were related in any way to the igneous rocks. Previous field work (Bridgwater, Sutton \& Watterson, 1966) suggested that considerable recrystallisation under granulite facies conditions of the country rocks has occurred around the intrusions. The igneous suite varies in composition from norite to quartz monzonite and quartz syenite. Locally mantled potash feldspars are developed and the rocks have been described in regional accounts as "rapakivi granites". The country rocks in eastern South Greenland consist of flat-lying migmatised metasediments intruded by subconcordant granodiorite sheets. Both the migmatites and the granodiorite sheets were recrystallised under amphibolite facies metamorphic conditions resulting in cordierite-sillimanite-garnet-bearing assem- 


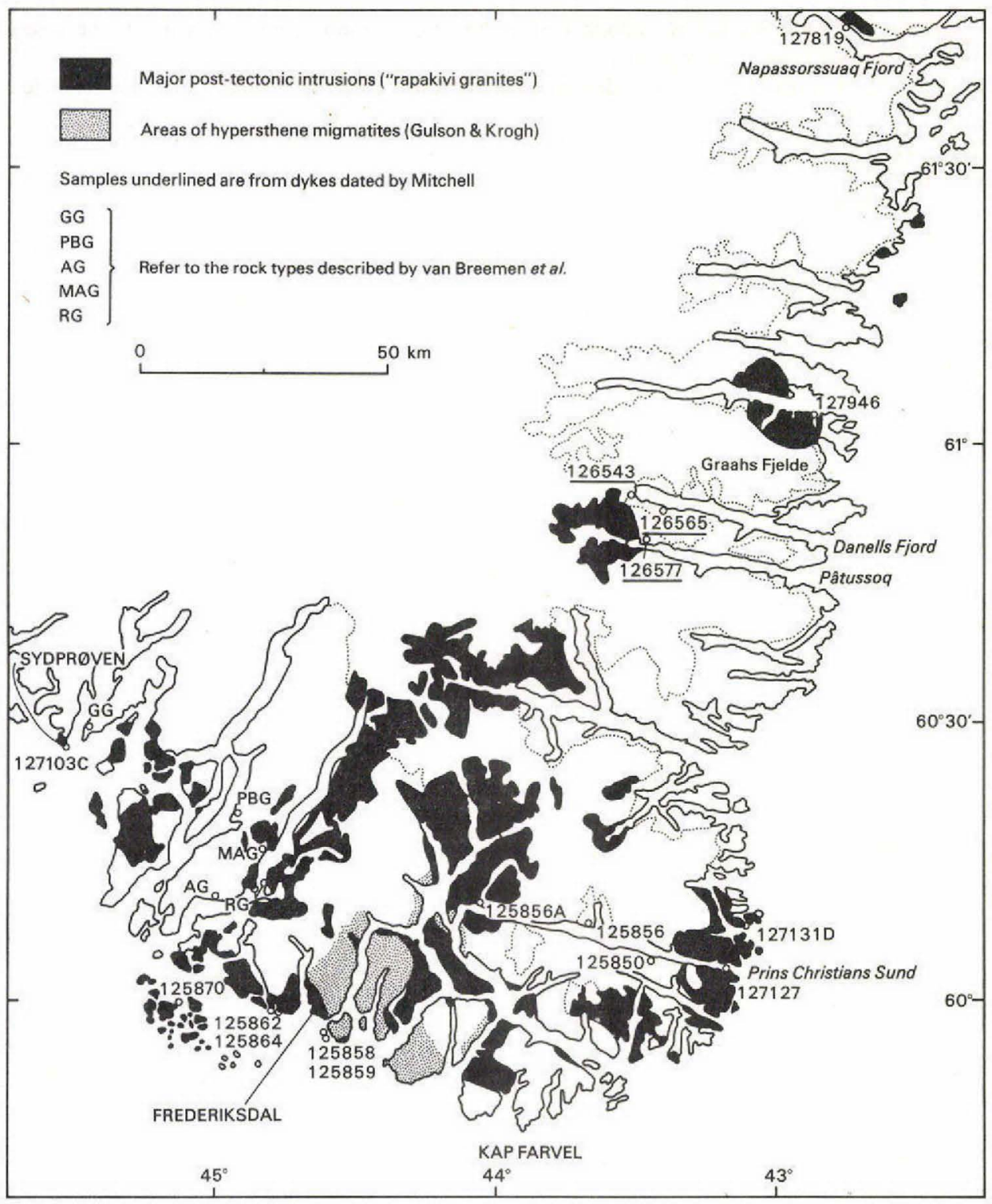

Fig. 6. Map of part of South Greenland showing major areas of rapakivi granites and hypersthene-bearing migmatites, together with most localities of samples mentioned in Gulson \& Krogh, van Breemen et al. and Mitchell.

blages. Between Kap Farvel and Frederiksdal and close to the lower contacts of the late intrusive granites, the migmatites show less well-defined lithological divisons and contain hypersthene-cordierite-garnet assemblages. A major part of the 
hypersthene-bearing migmatites consists of coarse-grained granite with euhedral potash feldspar phenocrysts. The samples for the main study were taken to establish whether there was any isotopic evidence for relating the formation of the hypersthene-bearing migmatites to the emplacement of the granites (Bridgwater \& Watterson, 1967).

Further aims were to relate the bodies of similar post-tectonic granites mapped in southern East Greenland (Andrews et al., 1971) with those mentioned above from farther south, and to investigate rocks from either side of a major boundary mapped by Andrews et al. (1971) between early Precambrian rocks to the north and younger Precambrian rocks to the south.

\section{The results}

The zircons were analysed by the Krogh hydrothermal method, and this, along with the expected precision of the analyses in this report, is documented in the Carnegie Institution of Washington Year Book No. 70 issued Dec. 1971 and submitted to Geochimica et Cosmochimica Acta, Jan. 1972. Detailed results and conclusions of the zircon analyses presented here in preliminary form will be published in the near future.

Most of the data are given on a detailed "concordia" plot in fig. 7 and some diffusion ages are given in table 4 . Table 3 gives details of the samples shown in the "concordia" plot.

1) The zircons are highly concordant; data for the late intrusions and the early

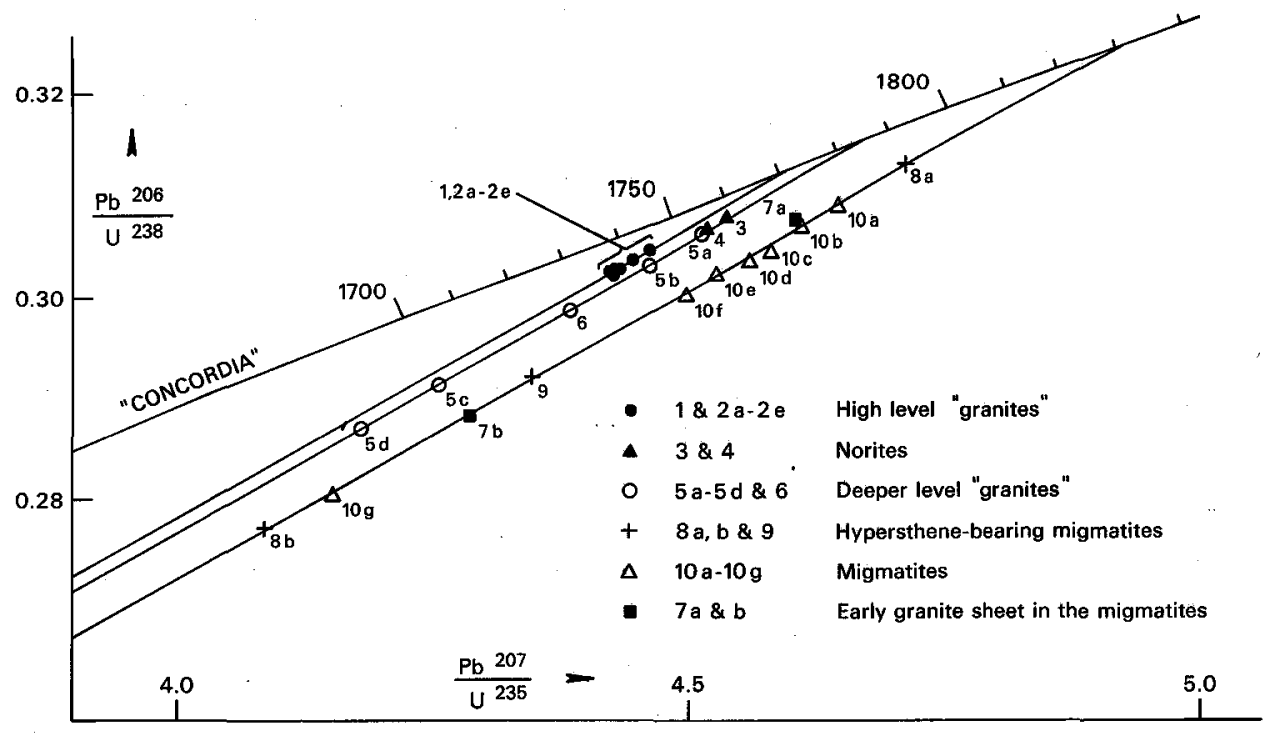

Fig. 7. A "concordia" plot of zircon dates from South Greenland. (Gulson \& Krogh). 
Table 3. Details of samples from South Greenland included on the 'concordia' plot - fig. 7

\begin{tabular}{|c|c|c|c|}
\hline $\begin{array}{l}\text { No. on } \\
\text { "concordia" }\end{array}$ & $\begin{array}{c}\text { GGU } \\
\text { sample no. }\end{array}$ & Rock type & Locality \\
\hline 1 & $127131 \mathrm{D}$ & $\begin{array}{l}\text { Coarse-grained } \\
\text { quartz monzonite }\end{array}$ & $\begin{array}{l}\text { Aluk tunordleq, } \\
60^{\circ} 09^{\prime} \mathrm{N}, 43^{\circ} 07^{\prime} \mathrm{W}\end{array}$ \\
\hline $2 \mathrm{a}, \mathrm{b}, \mathrm{c}, \mathrm{d}, \mathrm{e}$ & 127127 & Adamellite & $\begin{array}{l}\text { Prins Christians Sund } \\
\text { weather station, } \\
60^{\circ} 03^{\prime} \mathrm{N}, 43^{\circ} 12^{\prime} \mathrm{W}\end{array}$ \\
\hline 3 & 125864 & Norite & $\begin{array}{l}\text { Ikigait, } \\
60^{\circ} 00^{\prime}, \mathrm{N}, 44^{\circ} 47^{\prime} \mathrm{W}\end{array}$ \\
\hline 4 & $125856 \mathrm{~A}$ & Norite & $\begin{array}{l}\text { Prins Christians Sund, } \\
60^{\circ} 10^{\prime} \mathrm{N}, 43^{\circ} 12^{\prime} \mathrm{W}\end{array}$ \\
\hline $5 \mathrm{a}, \mathrm{b}, \mathrm{c}, \mathrm{d}$ & 125862 & $\begin{array}{l}\text { Medium-grained } \\
\text { adamellite }\end{array}$ & $\begin{array}{l}\text { Ikigait, } \\
59^{\circ} 59^{\prime} \mathrm{N}, 44^{\circ} 48^{\prime} \mathrm{W}\end{array}$ \\
\hline 6 & 125870 & $\begin{array}{l}\text { Coarse-grained } \\
\text { adamellite }\end{array}$ & $\begin{array}{l}\text { Angissoq Loran Station, } \\
59^{\circ} 59^{\prime} \mathrm{N}, 45^{\circ} 10^{\prime} \mathrm{W}\end{array}$ \\
\hline $7 \mathrm{a}, \mathrm{b}$ & 125850 & $\begin{array}{l}\text { Early garnet } \\
\text { granodiorite }\end{array}$ & $\begin{array}{l}\text { Prins Christians Sund, } \\
60^{\circ} 05^{\prime} \mathrm{N}, 43^{\circ} 23^{\prime} \mathrm{W}\end{array}$ \\
\hline $8 a, b$ & 125858 & $\begin{array}{l}\text { Hypersthene-bearing } \\
\text { migmatite }\end{array}$ & $\begin{array}{l}\text { Qaersua island, } \\
59^{\circ} 57^{\prime} \mathrm{N}, 44^{\circ} 37^{\prime} \mathrm{W}\end{array}$ \\
\hline 9 & 125859 & $\begin{array}{l}\text { Hypersthene-bearing } \\
\text { granitic migmatite }\end{array}$ & $\begin{array}{l}\text { Sardlat island, } \\
59^{\circ} 58^{\prime} \mathrm{N}, 44^{\circ} 38^{\prime} \mathrm{W}\end{array}$ \\
\hline 10 a,b c, d, ef, $g$ & 125856 & $\begin{array}{l}\text { Amphibolite facies } \\
\text { migmatite }\end{array}$ & $\begin{array}{l}\text { Prins Christians Sund, } \\
60^{\circ} 08^{\prime} \mathrm{N}, 43^{\circ} 36^{\prime} \mathrm{W}\end{array}$ \\
\hline
\end{tabular}

Table 4. Diffusion ages 'of zircons from South Greenland

\begin{tabular}{c|l|l|c}
\hline $\begin{array}{c}\text { GGU } \\
\text { sample no. }\end{array}$ & \multicolumn{1}{c|}{ Rock type } & \multicolumn{1}{c}{ Locality } & $\begin{array}{c}\text { Age } \\
\text { (m.y.) }\end{array}$ \\
\hline 127190 & $\begin{array}{l}\text { High-grade orthogneiss (possibly a } \\
\text { metamorphosed intermediate volcanic } \\
\text { rock) }\end{array}$ & $\begin{array}{l}\text { Peninsula north of } \\
\text { Mogens Heinesen Fjord, } \\
62^{\circ} 24^{\prime} \mathrm{N}, 42^{\circ} 15^{\prime} \mathrm{W}\end{array}$ & 2809 \\
127137 & Hornblende monzonite & $\begin{array}{l}\text { Ikermit island, } \\
62^{\circ} 15^{\prime} \mathrm{N}, 42^{\circ} 05^{\prime} \mathrm{W}\end{array}$ & 1845 \\
127819 & $\begin{array}{l}\text { "Syenite" belonging to young intrusive } \\
\text { suite }\end{array}$ & $\begin{array}{l}\text { Napassorssuaq Fjord, } \\
61^{\circ} 46^{\prime} \mathrm{N}, 42^{\circ} 42^{\prime} \mathrm{W}\end{array}$ & 1789 \\
127946 & $\begin{array}{l}\text { Quartz syenite belonging to young } \\
\text { intrusive suite }\end{array}$ & $\begin{array}{l}\text { Graahs Fjelde, } \\
61^{\circ} 02^{\prime} \mathrm{N}, 42^{\circ} 50^{\prime} \mathrm{W}\end{array}$ & 1784 \\
$127103 \mathrm{c}$ & Sydprøven "granite” & $\begin{array}{l}\text { Sydprøven village, } \\
60^{\circ} 27^{\prime} \mathrm{N}, 45^{\circ} 33^{\prime} \mathrm{W}\end{array}$ & 1814 \\
& &
\end{tabular}


migmatites and granites clearly define two unique isochrons with an apparent age difference of $40 \mathrm{~m}$.y. Initial grain mount studies showed that the zircons from the late intrusions differed markedly from those of the gneisses.

2) The high-grade migmatites show zircon populations which belong to the same type as those of the amphibolite facies gneisses and early granites both in form and in isotopic character. There is no isotopic evidence for resetting the zircons at the time of emplacement of the late intrusions.

3) An expected complex history for the migmatites and early granodiorites did not eventuate: seven magnetic and size fractions (numbers $10 \mathrm{a}$ to $10 \mathrm{~g}$ ) from this sample plot on the same chord, demonstrating either, (a) that the zircons were completely reset at 1832 m.y., or (b) that this was the time of formation of the rock. The latter is unlikely since the migmatites are clearly composed of several different rock units. Preliminary data on a paragneiss associated with the migmatite and from the hypersthene-bearing migmatites (numbers 8 and 9) show them to contain some older zircons (from 1860 to 2000 m.y.) which suggests that the age obtained for the migmatites is one of resetting.

4) It is possible to generate two chords for the granites: one related to the deeper level intrusions (1784 m.y.) and the other related to the higher level types, having a lower age of 1772 m.y. These represent geochronologically distinct events.

5) The norites associated with the deeper level late intrusions are of the same age and probably related genetically.

6) Analyses of the non-magnetic fractions $(-100 /+200$ mesh) from similar intrusions at Graahs Fjelde (GGU 127946) and Napassorssuaq Fjord (GGU 127819) indicate the same age of intrusion as those in the south (1784 and 1789 m.y. diffusion ages respectively).

7) The lower extrapolation on the "concordia" may be meaningless but an intercept is observed at $450-500 \mathrm{~m} . \mathrm{y}$. if the upper linear part of the Tilton continuous diffusion curve is extended.

8) The field and K/Ar evidence (Andrews et al., 1971; Bridgwater, 1971) for a major boundary to the south of Mogens Heinesen Fjord is corroborated. The diffusion age of 1845 m.y. for a hornblende diorite-monzonitic intrusion (GGU 127137) gives a maximum age for metamorphic events affecting rocks of this suite to the south. The 2808 m.y. (2799 m.y. 207/206 age) from a high-grade amphibolite facies gneiss (GGU 127190) of supposed intermediate volcanic supracrustal origin from north of the boundary can either be interpreted as the age of deposition of these rocks or (geologically more probably) as the age of the regional high-grade metamorphism affecting them.

9) The diffusion age of $1814 \mathrm{~m} . \mathrm{y}$. on sample GGU $127103 \mathrm{c}$ from the posttectonic Sydprøven granite (Bridgwater, 1963) suggests that this body was emplaced after the main event dated from the gneisses and migmatites but before the other members of the post-tectonic suite dated from South Greenland. The zircons from this sample differ markedly from those of the other intrusions studied. 


\section{Acknowledgements}

We wish to thank Drs. H. S. Yoder and S. R. Hart for extensive use of facilities in the Geophysical Laboratory and Department of Terrestial Magnetism respectively, Carnegie Institution of Washington, and $\mathrm{K}$. Burrhus for maintenance of the mass spectrometer used in this study.

\section{References}

Andrews, J. R., Bridgwater, D., Gulson, B. [L.] \& Watterson, J. [S.] 1971: Reconnaissance mapping of South-East Greenland between $62^{\circ} 30^{\prime} \mathrm{N}$ and $60^{\circ} 30^{\prime} \mathrm{N}$. Rapp. Grønlands geol. Unders. 35, 32-38.

Bridgwater, D. 1963: A review of the Sydprøven granite and other "New granites" of South Greenland. Meddr dansk geol. Foren. 15, 167-182.

Bridgwater, D. 1971: Routine K/Ar age determinations on rocks from Greenland carried out for GGU in 1970. Rapp. Grønlands geol. Unders. 35, 52-60.

Bridgwater, D. \& Watterson, J. S. 1967: Igneous intrusions and associated rocks of the mangerite-charnockite suite. Nature, Lond. 213, 897 only.

Bridgwater, D., Sutton, J. \& Watterson, J. S. 1966: The Precambrian rapakivi suite and surrounding gneisses of the Kap Farvel area, South Greenland. Rapp. Gronlands geol. Unders. 11, 52-54.

B.L.G.

Universität Bern, Mineral.-Petrograph. Institut, Sahlistrasse 6, 3012 Bern, Switzerland.

T.E.K.

Geophysical Laboratory,

Carnegie Institution of Washington, 2801 Upton Street, Washington D. C. 20008, U.S.A.

\section{K/Ar AGES OF MICA LAMPROPHYRES FROM SOUTHERN EAST GREENLAND}

\section{J. G. Mitchell}

Interpretations in collaboration with J. R. Andrews

$\mathrm{K} / \mathrm{Ar}$ age determinations have been carried out on three dyke samples from a suite of post-tectonic mica lamprophyres in the inner parts of Danells Fjord and Pâtussoq (Andrews et al., 1971 \& in prep.). The dykes were intruded through a metamorphosed supracrustal sequence and in turn transected by an east-w.est trending dolerite in Danells Fjord.

The following dates indicate that the dykes belong to two episodes of activity which form part of the evolution of the Gardar igneous province of South Greenland. An east-west trending pyroxene-mica lamprophyre dyke was intruded 